\title{
Response of Promising Sugarcane Genotypes for Salinity Tolerance
}

\author{
B. Vajantha*, M. Hemanth Kumar, T. M. Hemalatha and K. R. Tagore \\ Agricultural Research Station, Perumallapalle, ANGEAU, Tirupathi, India \\ *Corresponding author
}

\begin{abstract}
A B S T R A C T
Keywords

Sugarcane genotypes, Salinity, Yield and Juice quality

Article Info

Accepted:

25 September 2020

Available Online:

10 October 2020

An experiment was conducted to evaluate salinity tolerance of promising sugarcane genotypes with microplot techniques at Agricultural Research Station, Perumallapalle, ANGRAU, Andhra Pradesh during 2018-19. Nine sugarcane genotypes along with four checks were studied for salinity tolerance with two treatments viz., control and salt treatment. Soil EC of $6 \mathrm{dS} \mathrm{m}{ }^{-1}$ was developed in salt treatment with external addition of salt water. Results revealed that the mean germination, single cane weight, sucrose and commercial cane sugar (CCS) were significantly differed by genotypes. The control treatment recorded higher mean germination $(65 \%)$, single cane weight $(1.062 \mathrm{~kg})$ and sucrose $(17.44 \%)$ than salt treatment $(54 \%, 1.000 \mathrm{~kg}$ and $15.83 \%$, respectively). Among genotypes Co 86032, $2012 \mathrm{~T} 58,2012 \mathrm{~T} 72$ showed less reduction in germination, $2012 \mathrm{~T}$ 81, Co 86032, 2012 T 58, 2012 T 72 and 2012 T 58 recorded less reduction in cane weight under saline conditions. The genotypes Co 86032, 2012 T 72 and 2003 V 46 showed

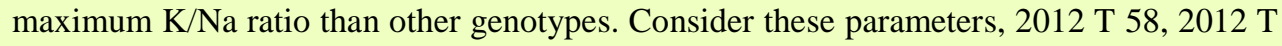
72, 2012 T 180 and Co 86032 genotypes showed salt tolerance.
\end{abstract}

\section{Introduction}

The beginning of $21^{\text {st }}$ century is marked by global scarcity of water resources, environmental pollution and increased salinization of soil and water. Increasing human population and reduction in land available for cultivation are two threats for agricultural sustainability (Shabhaz and Ashraf, 2013). Various environmental stresses viz., high winds, extreme temperature, soil salinity, drought and flood have affected the production and cultivation of agricultural crops, among these soil salinity is one of the most devastating environmental stresses, which causes major reduction in cultivated land area, crop productivity and quality. It has been estimated that worldwide $20 \%$ of total cultivated and $33 \%$ of irrigated agricultural lands are affected by high salinity. Furthermore, the salinized area is increasing at a rate of $10 \%$ annually for various reasons, including low precipitation, high surface evaporation, weathering of native rocks, irrigation with saline water and poor cultural practices. Problematic soils are a major limiting production factor for every major crop (Bacilio et al., 2004; Shannon and Grieve 1999). 
Sugarcane (Sacharun officinarum L.) is a typical glycophyte grown in arid and semiarid regions and frequently subjected to soil salinity (Lingle and Weigand, 1997). The crop is moderately sensitive to salinity. Salinity inhibits plant growth by ion toxicity, nutritional imbalances, osmotic effect and oxidative stress (Chinnusamy et al., 2005). Using the salt tolerant crops is one of the most important strategies to solve the problem of salinity. Salt tolerance in crops will also allow the more effective use of poor quality irrigation water. (Manchanda and Garg., 2008). The differential growth performance of plant species / genotypes under salinity may be related to their ability to uptake, transport of ions and salt exchange mechanisms. Salt tolerant genotypes compromises either in yield or quality and thus able to perform mechanisms. Keeping this in view present experiment was designed to study the relative salt tolerance of sugarcane genotypes grown in saline soils with EC of $6 \mathrm{dS} \mathrm{m}^{-1}$.

\section{Materials and Methods}

The experiment was conducted at Agricultural Research Station, Perumallapalle, Tirupati, ANGRAU, Andhra Pradesh during 20182019 by using micro plot, technique. Nine pre release sugarcane genotypes along with four standard checks were evaluated with two treatments viz., control and salt treatment (soil

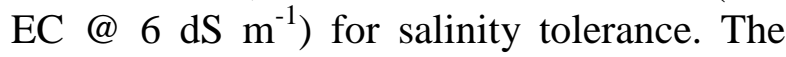
experiment was laidout in factorial RBD design with two replications. Ten single bud setts per each pot were planted during February, 2018 and harvested in January, 2019. The initial soil samples were collected and analyzed by following standard procedures. The analyzed data has been presented in table 1. Before planting of setts, soil EC was developed to $6 \mathrm{dS} \mathrm{m}^{-1}$ and maintained until harvest with addition of salt water contains $\mathrm{NaCl}, \mathrm{CaCl}_{2}$ and $\mathrm{Na}_{2} \mathrm{SO}_{4}$ in ratio of $2: 2: 1$ to salt treated pots. The plant samples were collected at grand growth stage for determination of $\mathrm{K}$ and $\mathrm{Na}$ content. The data on germination, cane length, girth, single cane weight, juice quality parameters like sucrose, commercial cane sugar (CCS), purity, $\mathrm{K} / \mathrm{Na}$ ratio in plant tissue were recorded in both the treatments for all genotypes. Data obtained from the experiment was statistically analysed by method described ny Panse and Sukhatme (1985). .

\section{Results and Discussion}

Characteristics like germination, cane weight, $\mathrm{Na}$ accumulation and $\mathrm{K}^{+} / \mathrm{Na}^{+}$ratio have been considered useful guide to assess plants for salt tolerance. Selection of genotypes on this basis is an important strategy to minimize yield losses in saline soils (Santa maria and Epstcin, 2001).

\section{Germination}

The germination of sugarcane significantly influenced by genotypes, treatments as well as with their interaction (Table 2). Maximum mean germination percent (76\%) was recorded with $2012 \mathrm{~T} 58$, but was found at par with Co 86032 (67\%). Among the treatments control pot showed significantly the highest mean germination $(65 \%)$ than salt treated pots (54\%). In interaction effect, genotype $2012 \mathrm{~T}$ 58 in control treatment recorded higher germination $(80 \%)$ and it was on par with other genotypes. Percent reduction on germination was less (3\% only) with Co 86032 followed by 2012 T 58 (8\%), $2012 \mathrm{~T}$ 72 (8\%), 2012 T 78 (8\%) under saline conditions. This data indicates that the genotypes Co 86032, 2012 T 58, 2012 T 72 showed salt tolerance than other genotypes. Recent reports also show that salinity adversely affects plant growth and development, hindering germination, seedling growth and enzyme activity (Seckin et al., 2009). 
Table.1 Initial soil properties

\begin{tabular}{|c|c|}
\hline Particulars & Value \\
\hline Soil pH & 7.37 \\
\hline Soil EC (dS m $\left.{ }^{-1}\right)$ & 0.391 \\
\hline Organic carbon $(\%)$ & 0.47 \\
\hline Available $N\left(\mathrm{~kg} \mathrm{ha}^{-1}\right)$ & 221 \\
\hline Available $\mathrm{P}_{2} \mathrm{O}_{5}\left(\mathrm{~kg} \mathrm{ha}^{-1}\right)$ & 42 \\
\hline Available $\mathrm{K}_{2} \mathrm{O}\left(\mathrm{kg} \mathrm{ha}^{-1}\right)$ & 210 \\
\hline
\end{tabular}

Table.2 Effect of salinity on germination and single cane weight of sugarcane genotypes

\begin{tabular}{|c|c|c|c|c|c|c|c|c|}
\hline \multirow[t]{2}{*}{ Genotypes } & \multicolumn{4}{|c|}{ Germination \% } & \multicolumn{4}{|c|}{ Single cane weight (kg) } \\
\hline & $\begin{array}{c}\text { Contr } \\
\text { ol }\end{array}$ & $\begin{array}{c}\text { Salt } \\
\text { treated }\end{array}$ & Mean & $\begin{array}{c}\% \\
\text { reduction }\end{array}$ & Control & $\begin{array}{c}\text { Salt } \\
\text { reated }\end{array}$ & Mean & $\begin{array}{c}\% \\
\text { reduction }\end{array}$ \\
\hline 2012 T58 & 80 & 72 & 76 & 8 & 1.017 & 1.004 & 1.010 & 1.4 \\
\hline 2012 T 72 & 68 & 60 & 64 & 8 & 1.011 & 0.999 & 0.999 & 1.2 \\
\hline 2012 T 73 & 65 & 55 & 60 & 10 & 0.990 & 0.880 & 0.935 & 11.2 \\
\hline $2012 \mathrm{~T} 78$ & 65 & 58 & 61 & 8 & 1.283 & 1.188 & 1.235 & 7.4 \\
\hline 2012 T 81 & 63 & 53 & 58 & 10 & 1.046 & 1.039 & 1.042 & 0.7 \\
\hline 2012 T 106 & 40 & 30 & 35 & 10 & 1.012 & 0.988 & 1.000 & 2.4 \\
\hline 2012 T 115 & 60 & 45 & 53 & 15 & 0.929 & 0.900 & 0.929 & 3.1 \\
\hline 2012 T 180 & 58 & 23 & 40 & 35 & 0.966 & 0.910 & 0.938 & 5.8 \\
\hline 2012 T 182 & 60 & 48 & 54 & 13 & 1.268 & 1.184 & 1.226 & 6.6 \\
\hline 2003 V 46 & 75 & 55 & 65 & 20 & 1.022 & 0.985 & 1.022 & 3.6 \\
\hline Co 99004 & 73 & 55 & 64 & 18 & 1.226 & 1.049 & 1.137 & 14.4 \\
\hline 2005 T 52 & 75 & 65 & 70 & 10 & 1.011 & 0.953 & 1.011 & 5.7 \\
\hline CO 86032 & 68 & 65 & 67 & 3 & 0.931 & 0.928 & 0.930 & 0.4 \\
\hline \multirow[t]{2}{*}{ Mean } & 65 & 54 & & & 1.062 & 1.000 & & \\
\hline & $\mathrm{CD}$ & $\mathrm{SE}(\mathrm{m})$ & & & $\mathrm{CD}(0.05)$ & $\mathrm{SE}(\mathrm{m})$ & & \\
\hline Varieties & 9.25 & 3.17 & & & 0.091 & 0.044 & & \\
\hline Treatments & 3.62 & 1.24 & & & 0.036 & 0.018 & & \\
\hline VxT & 13.08 & 4.49 & & & N.S. & 0.063 & & \\
\hline
\end{tabular}


Table.3 Effect of salinity on sucrose and CCS of sugarcane genotypes

\begin{tabular}{|c|c|c|c|c|c|c|c|c|}
\hline \multirow[t]{2}{*}{ Genotypes } & \multicolumn{4}{|c|}{ Sucrose (\%) } & \multicolumn{4}{|c|}{$\mathrm{CCS} * \%)$} \\
\hline & Control & $\begin{array}{c}\text { Salt } \\
\text { treated }\end{array}$ & Mean & $\begin{array}{c}\% \\
\text { reduction }\end{array}$ & Control & Salt treated & Mean & $\begin{array}{c}\% \\
\text { reduction }\end{array}$ \\
\hline 2012 T58 & 16.81 & 15.85 & 16.33 & 5.7 & 11.67 & 11.27 & 11.47 & 3.4 \\
\hline 2012 T 72 & 16.75 & 16.40 & 16.57 & 2.1 & 11.25 & 10.53 & 10.89 & 6.4 \\
\hline 2012 T 73 & 16.82 & 15.98 & 16.40 & 5.0 & 11.69 & 10.84 & 11.26 & 7.2 \\
\hline 2012 T 78 & 17.30 & 15.98 & 16.64 & 7.6 & 11.68 & 10.89 & 11.29 & 6.8 \\
\hline 2012 T 81 & 16.20 & 15.48 & 15.84 & 4.5 & 10.98 & 10.26 & 10.62 & 6.6 \\
\hline 2012 T 106 & 18.11 & 15.14 & 16.63 & 16.4 & 12.86 & 10.05 & 11.45 & 21.9 \\
\hline 2012 T 115 & 18.40 & 16.08 & 17.24 & 12.6 & 12.88 & 10.87 & 11.88 & 15.6 \\
\hline 2012 T 180 & 17.17 & 16.61 & 16.89 & 3.3 & 12.50 & 11.60 & 12.05 & 7.2 \\
\hline 2012 T 182 & 19.30 & 17.20 & 18.25 & 10.9 & 12.51 & 12.49 & 12.50 & 0.1 \\
\hline 2003 V 46 & 17.84 & 15.46 & 16.65 & 13.3 & 12.45 & 10.74 & 11.59 & 13.8 \\
\hline Co 99004 & 17.14 & 15.39 & 16.26 & 10.2 & 11.82 & 10.35 & 11.08 & 12.5 \\
\hline 2005 T 52 & 16.66 & 15.16 & 15.91 & 9.0 & 11.39 & 10.17 & 10.78 & 10.7 \\
\hline CO 86032 & 16.87 & 15.62 & 16.25 & 7.4 & 11.45 & 10.53 & 10.99 & 8.1 \\
\hline \multirow[t]{2}{*}{ Mean } & 17.44 & 15.83 & & & 12.02 & 10.80 & & \\
\hline & $\begin{array}{l}\text { CD } \\
(0.05)\end{array}$ & $\mathrm{SE}(\mathrm{m})$ & & & $\begin{array}{c}\text { CD } \\
(0.05)\end{array}$ & $\mathrm{SE}(\mathrm{m})$ & & \\
\hline Varieties & 0.359 & 0.444 & & & 1.389 & 0.476 & & \\
\hline Treatments & 0.916 & 0.174 & & & N.S. & 1.215 & & \\
\hline VxT & N.S. & 0.629 & & & N.S. & 1.719 & & \\
\hline
\end{tabular}

Table.4 Effect of salinity on $\mathrm{K}$ and Na ratio in plant of sugarcane genotypes

\begin{tabular}{|c|c|c|}
\hline \multirow{2}{*}{ Genotypes } & \multicolumn{2}{|c|}{ K/Na ratio } \\
\cline { 2 - 3 } & Control & Salt treated \\
\hline 2012 T58 & 5.17 & 4.35 \\
\hline $\mathbf{2 0 1 2}$ T 72 & 5.38 & 4.33 \\
\hline $\mathbf{2 0 1 2}$ T 73 & 5.20 & 4.18 \\
\hline 2012 T 78 & 5.23 & 4.40 \\
\hline $\mathbf{2 0 1 2}$ T 81 & 5.24 & 4.28 \\
\hline $\mathbf{2 0 1 2}$ T 106 & 5.20 & 4.34 \\
\hline $\mathbf{2 0 1 2}$ T 115 & 5.10 & 4.28 \\
\hline $\mathbf{2 0 1 2}$ T 180 & 5.00 & 4.40 \\
\hline $\mathbf{2 0 1 2}$ T 182 & 5.20 & 4.38 \\
\hline $\mathbf{2 0 0 3}$ V 46 & 5.23 & 4.26 \\
\hline Co 99004 & 5.13 & 4.47 \\
\hline $\mathbf{2 0 0 5}$ T 52 & 5.12 & 4.26 \\
\hline CO 86032 & 5.48 & 4.52 \\
\hline
\end{tabular}




\section{Single cane weight}

The data pertaining to single cane weight was presented in table 2. Genotypes and treatments showed significant effect on single cane weight where as interaction effect was non significant. $2012 \mathrm{~T} 78$ has higher mean single cane weight $(1.235 \mathrm{~kg})$ which was at par with $2012 \mathrm{~T} 182(1.226 \mathrm{~kg})$. Control pot showed significantly the highest single cane weight $(1.062 \mathrm{~kg})$ over salt treated pot. The genotype Co 86032 showed less percent reduction in single cane weight $(0.4 \%)$ under salt toiled pots followed by $2012 \mathrm{~T} 81(0.7 \%)$, 2012 T $72(1.2 \%)$ and 2012 T $58(1.4 \%)$. Reduction in cane weight of sugarcane genotypes in salt treatment might be due to toxicity of $\mathrm{Na}^{+}$ions which causes imbalance of other nutrients like $\mathrm{K}^{+}$and $\mathrm{Ca}^{+}$. It consequently resulted in metabolic imbalances which reduces growth and yield. Chinnasamy et al., 2005 also reported that under salt stress, the predominant cause of reduced plant growth appeared to be ion toxicity rather than osmotic stress. The magnitude of decline in cane weight among sugarcane genotypes varied possibly because of their differential selectivity for $\mathrm{K}^{+}$ions over $\mathrm{Na}^{+}$(Ashraf et al, 2007; Asch et al., 2000).

\section{Sucrose}

Sugarcane genotypes grown in control pots resulted significantly the highest mean sucrose $(17.44 \%)$ than salt treated pots $(15.83 \%)$. The sucrose content in sugarcane genotypes has significant difference (Table 3). Even though $2012 \mathrm{~T} 182$ showed the highest mean sucrose (18.25\%), deterioration of sucrose is more under salt treated pots (10.9\%). Among genotypes, $2012 \mathrm{~T} 72$ showed less deterioration (2.1\%) followed by $2012 \mathrm{~T} 180$ (3.3\%), $2012 \mathrm{~T} 81(4.5 \%)$ and 2012 T $58(5.7 \%)$ under saline conditions. The interaction effect between genotypes and treatments was non significant. Similar findings were also observed by Vajantha et al., 2017.

\section{Commercial cane sugar (ccs)}

A perusal of data in table 3 indicated that declining of CCS $(10.80 \%)$ under salt treatment than control $(12.02 \%)$. CCS was significantly influenced by genotypes. Among the genotypes 2012 T 182 recorded higher mean CCS $(12.50 \%)$ and was found to at par with $2012 \mathrm{~T} 180,2012 \mathrm{~T} 115,2003 \mathrm{~V}$ 46, 2012 T 106, 2012 T 58, 2012 T 73 and 2012 $\mathrm{T} 72$. The interaction between genotypes and treatments was found to non significant. Wahid et al., (1997) also observed that the CCS has been differed with different sugarcane genotypes.

\section{Potassium sodium ratio in plant}

The $\mathrm{K} / \mathrm{Na}$ ratio was more in control than salt treatment. Applied salinity causes increased $\mathrm{Na}^{+}$concentration and consequently reduced $\mathrm{K}^{+} / \mathrm{Na}^{+}$ratio, however it varied widely among various sugarcane genotypes. Among the genotypes Co 86032 showed minimum $\mathrm{K}^{+} / \mathrm{Na}^{+}$ratio (5.48) followed by $2012 \mathrm{~T} 72$ (5.38) and $2003 \mathrm{~V} 46$ (5.23). The $\mathrm{K}^{+} / \mathrm{Na}^{+}$ratio in plant under control conditions ranged from 5.00 to 5.48. It reduced to the range from 4.18 to 4.52 under saline conditions. Reduction in $\mathrm{K}^{+} / \mathrm{Na}^{+}$ratio of sugarcane genotypes in the presence of salinity could be due to the antagonism of $\mathrm{Na}^{+}$and $\mathrm{K}^{+}$. (Mohmoud Shoneili et al., 2011 and Vajantha et al., 2017.

From this data, it is concluded that sugarcane genotypes showed significant difference in germination, single cane weight, sucrose and $\mathrm{K}^{+} / \mathrm{Na}^{+}$ratio when grown under saline conditions. The genotypes $2012 \mathrm{~T} \mathrm{58,2012 \textrm {T }}$ 72, 2012 T 180 and Co 86032 were suitable for saline conditions. 


\section{References}

Asch, F., Dingkuhn, M., Dorffling, K., and Miezan, K., 2000. Leaf $\mathrm{K} / \mathrm{Na}$ ratio predicts salinity induced yield loss in irrigated rice. Euphytica. 113:109-118.

Ashraf, M., Rahmatullah, S., Kanwar, M.A., Tahi, A., and Ali, L., 2007. Differential salt tolerance of sugarcane genotypes. Pakistahn Journal of Agricultural Sciences. 44(1):85-89.

Bacilio, M., Rodriguez, H., Moreno, M., Hernandez Juan-Pablo., Bashan, Y., 2004. Mitigation of salt stress in wheat seedlings by a gfp-tagged Azospirillum lipoferum. Biological Fertility Soils. 40:188-193.

Chinnusamy, V., Jagender, A., and Zhu, J. K., 2005. Understanding and improving salt tolerance in plants. Crop Science. 45(2):437-448.

Lingle, S. E., and Weigand, C.L., 1997. Soil salinity and sugarcane juice quality. Field Crops Research. 54: 259-268.

Mahmoud shomeili, Majid nipour, Mosa meskarbashee, and Rajabi memari., 2011. Evaluation of sugarcane (Saccharum officinarum L.) somaclonal variants tolerance to salinity in vitro and in vivo cultures. African Journal of Biotechnology. 10(46):9337-9343

Manchanda, G., Garg, N., 2008. Salinity and its effects on the functional biology of legumes. Acta Physiological Plant.
30:595-618.

Panse, V. G., and Sukhatme, P. V., 1985. Statistical methods for agricultural research, New Delhi.

Santa maria, G. E., and Epstein, E., 2001. Potassium/Sodium selectivity in wheat and the amphiploid cross wheat. Plant Science. 160:523-534.

Seckin, B., Sekmen, A.H., Turkan, I., 2009. An enhancing effect of exogenous mannitol on the antioxidant enzyme activities in roots of wheat under salt stress. Journal of Plant Growth Regulators. 28:12-20.

Shabhaz, M., and Ashraf, M., 2013. Improving salinity tolerance in cereals. Crit. Rev. Plant Sci. 32:237249.

Shannon, M.C., Grieve, C.M., 1999. Tolerance of vegetable crops to salinity. Scientific Horticulturae. 78:538

Vajantha, B., Hemanth Kumar, M., Hemalatha, T. M., Tagore, K., Sarala, N. V., and Subbarao, M., 2017. Evaluation of promising pre release sugarcane genotypes for salinity tolerance. Proceedings of $47^{\text {th }}$ Annual convention of SISSTA. 63-67.

Wahid, A., Rao, A.R., and Rasul, E., 1997. Identification of salt tolerance traits in sugarcane lines. Field crops Research. 54:9-17.

\section{How to cite this article:}

Vajantha, B., M. Hemanth Kumar, T. M. Hemalatha and Tagore, K. R. 2020. Response of Promising Sugarcane Genotypes for Salinity Tolerance. Int.J.Curr.Microbiol.App.Sci. 9(10): 3884-3889. doi: https://doi.org/10.20546/ijcmas.2020.910.447 